\title{
Three I know not what: The influence of Greek philosophy on the doctrine of Trinity
}

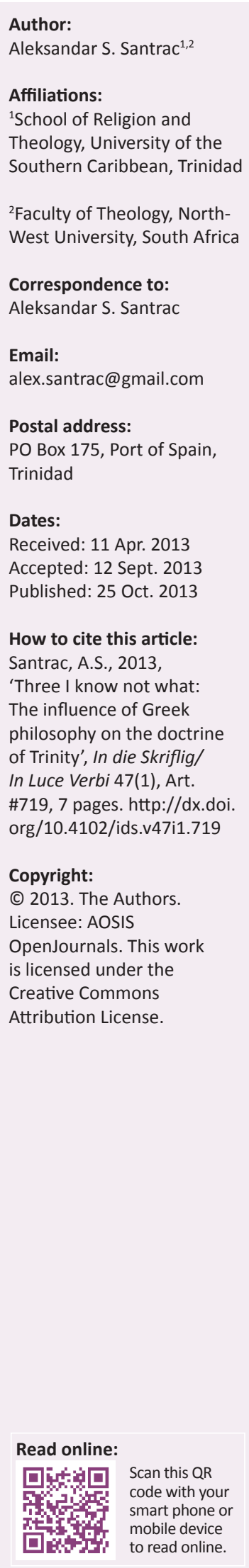

This article examines the origins of the traditional or orthodox Trinitarian formula. The main objective is to clarify to what extent the traditional Christian doctrine of the Trinity (Nicene formula) has been influenced by Greek philosophy. Through contemporary theological dialogue on this issue, the research focuses on the comparison between the traditional formulation of the doctrine of Trinity, influenced by Greek philosophy and the biblical revelation of the godhead. The conclusion is that the trinitarian formula might not be a dogmatic teaching, but a mystery (a dehellenisation of the concept of Trinity) and that the Church fathers and the post-Nicene church used the Greek philosophical-theological expressions for Trinity, already present in Scriptures in its doxological and liturgical form, primarily for the purpose of contextualisation.

Die misterie van die Drie-eenheid: Die invloed van die Griekse filosofie op die leerstelling van die Drie-eenheid. Hierdie artikel ondersoek die oorsprong van die tradisionele of ortodokse trinitariese leerstuk. Die hoofdoel is om uit te vind tot watter mate die tradisioneel Christelike leer oor die Drie-eenheid (Niceense formule) deur die Griekse filosofie beïnvloed is. Deur die hedendaagse teologiese debat oor hierdie onderwerp na te gaan, fokus die navorsing op 'n vergelyking tussen die tradisionele formulering van die leer van die Drie-eenheid soos beïnvloed deur die ortodokse Griekse filosofie en deur die bybelse openbaring van die godheid. Die slotsom waartoe gekom word, is dat die trinitariese formule moontlik nie 'n dogmatiese leerstuk was nie, maar 'n misterie ('n dehellenisering van die Drie-eenheidsbegrip). Die kerkvaders en die post-Niceense kerk het die Griekse filosofies-teologiese uitdrukkings vir die Drie-eenheid, wat alreeds in die Skrif in sy doksologiese en liturgiese vorm voorgekom het, moontlik slegs vir die doel van kontekstualisering gebruik.

\section{Introduction}

The doctrine of the Trinity is one of the most fundamental doctrines of Christian faith. A number of ancient and even contemporary theologians claim that the doctrine originated in Greek speculative philosophy and that it does not reflect a biblical view of God. In contrast, the majority of Catholic, Orthodox and Protestant or evangelical scholars deny these findings on the basis of clear biblical testimony about the Trinity although the term itself is not used in Scripture. It seems obvious that the orthodox or traditional church's trinitarian formula is grounded on at least some metaphysical ideas and models derived from Greek thinking. The main objective of this article is to explore the extent to which the traditional Christian doctrine of the Trinity (Nicene formula) is influenced by Greek philosophy. There are three main possibilities: (1) The traditional doctrine of the Trinity has its origin in Greek philosophical thinking; (2) the traditional doctrine of the Trinity is greatly influenced by the conceptual framework of Greek philosophy; or (3) the traditional doctrine of the Trinity is purely biblical teaching without any conspicuous or significant influence from Greek philosophical thinking.

The next section of this article will provide a brief overview of mature Greek philosophy (Plato, Aristotle, Neo-Platonism, Gnosticism, etc.) with an attempt to identify the potential influences that these philosophical systems may have had on the traditional formulation of the triune God. The subsequent section will compare the orthodox formulations of the Trinity and the trinitarian formulas found in the Bible. This will be done more as a theological dialogue than an exegetical task. Finally, the implications of this research that might contribute to the modern development of the understanding of the Trinity, will be drawn out. The possibility of developing a contextual theology of the Trinity will be addressed. Although the principles that will be examined have wider applications, the developing of an African trinitarian theology will also be briefly examined. 


\section{Greek philosophy and trinitarian dogma \\ Plato and the Trinity}

It is widely recognised that Platonic philosophy had a significant influence on the development of the Christian doctrine of God. According to some church fathers, Plato's idea of a Good (the Idea of the Good) has been recognised as analogous with the notion of a Christian God.

Beyond this, the Demiurge or Architect or Creator of the universe, ${ }^{1}$ described in a well-known dialogue Timaeus, has been identified (in middle Platonism) as the Mind (Nous) or Logos of God. Late Platonic philosophy speaks vaguely about a third divine entity, a World Soul or Psyche (Marsh 1994:55). The relationship between the Form of the Good and the Demiurge is not fully explained in Plato's thought. Some scholars do not interpret the passages about the Demiurge in Timaeus literally. What is clear, however, is that the Demiurge is eventually equated with Logos (in Stoicism) and subordinated to the supreme God. This Logos eventually becomes equated with the Logos of the Prologue of St. John's Gospel (Dillon 1989:2-3). Arians might have used this principle in their attack on the traditional doctrine of Trinity.

Thomas E. Gaston from Oxford University claims in his article 'The influence of Platonism on the Early Apologists' (Gaston 2009) that Justin Martyr borrows Plato's concept of God and that he is not an isolated case. Gaston (2009) notes:

There are clear instances of Platonic influence upon the second century Christian writers. Justin's pupil Tatian uses the same analogies to describe the emanation of the Logos and ascribes the role of interaction with the world to the Holy Spirit, probably because he equates the Spirit with the World-Soul. Athenagoras uses the Platonic terms 'Nous' and 'Logos' to describe the Son, and identifies the Logos with the sum of Forms. Both Athenagoras and Clement of Alexandria quote Plato's Letter to demonstrate the necessity of three principles. From the end of the second century Platonism became engrained in Christian discourse about God. (p. 576, [author's own emphasis])

Therefore, the Christian Trinity or the inner dynamics of the relationship between the Father, Son and Holy Spirit have been formulated using Plato's distinction between the Good, Nous and Pneuma (World Soul).

The further development of the Platonic understanding of three principles was made by Middle Platonists (ca. 90 BC to the 3rd century AD). According to Gaston (2009):

The influence of Middle Platonism upon the development of Christianity, particularly on the development of the doctrine of God, is undeniable. Despite Paul's warnings about the 'wisdom of the world', Christians found natural allies in the monotheistic Platonists.

1.The 'Demiurge's reasoning, however, is practical, not theoretical. The Demiurge, Burnyeat claims, works with given materials and when he creates the cosmos, he does not have a free choice, but has to adjust his plans to them. Although we know that the Demiurge is supremely benevolent towards his creation, none of us know that the Dis is could be certain of his practical reasons for framing the cosmos the way he did. That is why anyone aiming at disclosing them cannot but come up with "probable" answers. Plato's cosmology is then eikos in the two senses of the word, for it is both "reasonable" and "probable". But why does Plato call it a muthos? Because, Burnyeat argues, the Timaeus cosmology is also a theogony (for the created cosmos is for Plato a god), and this shows Plato's intention to overcome the traditiona opposition between muthos and logos' (Partenie 2011:2)
However, the influence of Platonism had greater impact than the early apologists could have realised. Not only did they introduce the triadic conception of the God-head but, eventually, the NeoPlatonists would be instrumental in establishing the coequality of the members of the Trinity. (p. 578, [author's own emphasis])

Neo-Platonism, consequently, has a crucial influence on the doctrine of Trinity formulated in the golden age of the church fathers. Before the analysis of this Hellenistic inspiration used by Christian apologists, let us briefly look at Aristotle's contribution to the development of the Christian doctrine of the Godhead.

\section{Aristotle and the Trinity}

Gregory of Nyssa (ca. 335-395), one of the Cappadocian fathers, was substantial influenced by Aristotle's Categories in his development of the doctrine of Trinity. ${ }^{2}$ Aristotle's concept of ousia (substance or essence) was fully adopted, though with reinterpretation. Gregory also accepted the distinction between primary and secondary substance from Aristotle's Metaphysics ${ }^{3}$ although he also transcends the distinction with his unique formulation of the Trinity (Allen 1985:96-97).

Basil the Great (329-379 AD), furthermore, borrowed Aristotle's distinction between universal and particular categories. Basil's terminology is totally compatible with Aristotle's. His theory of substance, used later to describe the Persons of the Trinity, is explained and elaborated by Aristotelian philosophical language (Jacobs 2008:337).

Finally, Aristotle's Unmovable Mover from Metaphysics has also been identified as the Christian God (the Father) in distinction from the Demiurge or Creator (Dillon 1989:5).

Therefore, long before Thomas Aquinas, Aristotle had exercised considerable influence upon the formulation of the Christian concept of the triune God.

\section{Stoicism and the Trinity}

Stoicism represents mature Hellenistic philosophy. The Stoic concept of Logos became the essential parallel for the Christian understanding of the Son of God.

Dynamically speaking, the Stoic Logos is 'the sum total of the spermatic reason-principles which permeate the physical world and give it form' (Dillon 1989:3). Philo of Alexandria used this concept and personified it. He described Logos as the 'Son' of God and Sophia (Wisdom). Philo personified the Stoic Logos. ${ }^{4}$ Though Philo called the Logos both 'the Son of 2.The Categories (Lat.Categoriae, Greek Katnvopial Katēgoriai) is a text from Aristotle's Organon that enumerates all the possible kind of things that can be the subject or the predicate of a proposition.

3.Metaphysics speaks about being, causation, substance, form, matter and what is important here about the nature of God as a prime Mover.

4.'Philo identifies YHWH as the Platonic One and thus has "'an emphatic doctrine of divine transcendence"'. God is "'qualityless", "unnameable" and "unutterable"', and thus altogether incomprehensible to the human mind. The perfect transcendence of YHWH entails that he cannot relate directly to the world. Following other Middle of YHWH entails that he cannot relate directly to the world. Following other Middle Platonic systems, Philo proposes a hierarchy of intermediaries. Philo cannot deny that YHWH is Creator, since the Old Testament (OT) describes him as such, therefor he posits two creations. First, YHWH creates the intelligible (immaterial) world (the Realm of the Forms), which Philo also identifies as the Logos. Then, through the mediation of the Logos, the sensible (material) world is created in the image of the intelligible world' (Gaston 2009:574). 
God' and 'the second god', it is not quite clear whether he regarded the Logos as a person (Gaston 2009:575). Catholic scholars deny any similarity between Philo's Logos and St. John's Logos. The counter-argument is that John's Logos is conceptually borrowed from the OT $(\operatorname{Pr} 8)$, viewing Logos as the embodiment of God's Wisdom (Garrigou-Lagrange 1952:41).

Nevertheless, it cannot be denied that the Stoic Logos was eventually recognised as the Son of God in Christian faith. A duality of deities, of course, represented a serious problem for Christian apologists. Apologists, under the influence of Stoicism, resolved the problem by making a distinction between the immanent Word or Thought (logos endiathetos) and the expressed Word or Thought (logos prophorikos). The Logos or the Son always existed with God the Father as logos endiathetos. However, when the Father willed to create the world, he expressed his Word (logos endiathetos) which became logos prophorikos. The conclusion that follows is: 'Though two distinct successive stages of existence are here attributed to the Logos, it is the very same Logos who subsists in both' (Marsh 1994:60). This is the response that Christian apologists gave when they were confronted with the problem of dual divinities.

\section{Neo-Platonism and Trinity}

Fourth- and 5th-century theologians of the Christian Church (Augustine and Gregory of Nyssa as well as other Cappadocians) appropriated the ideas of Plotinus (ca. 204/5270) the father of Neo-Platonism, regarding three divine hypostaseis. Plotinus' hierarchy of divinity (the One, Mind and Soul) was rejected. However, the Christian doctrine of the Trinity still represents a modification of Plotinus' teachings.

For Plotinus, everything that exists is in some sense unified. The unity of the One, the source of this unity, can be described only by negation (apophatic theology or via negativa). ${ }^{5}$ Diogenes Allen (1985), in his Philosophy for Understanding Theology, clarifies the point that Christianity, however, does not believe in the unity of God as a unity of a building, organism or a species. The divine unity is a richer one. The unity of God does not prevent Christian theology of speaking about three persons in the Being of God though the nature of the divine unity in plurality is the mystery of his Being. Christianity does not believe in radiation or emanation by necessity (as Plotinus did), but in the eternal coexistence of three Persons of the Godhead (Allen 1985:82-86).

The three divine principles expounded by Neo-Platonism also influenced Augustine, representing a good approximation to the Augustinian trinity (Stead 1989:72). Nevertheless, Christopher Stead (1989:73), in his 'Augustine's philosophy of being,' argues that most of the ideas about the One, Mind and Soul were foreign to Augustine, who accepted the Nicene doctrine of a Trinity of equal Persons. For Augustine, God is not beyond being as the One was for Plotinus. It seems that this church father was under the influence of an older tradition of Platonic thought which understood God as Mind (1989:73).

Therefore, though the Nicene fathers were heavily influenced by Neo-Platonism with its distinction between three divine entities, the Christian understanding of Trinity is still substantially different from the teachings of Plotinus regarding the relationship within the Godhead.

In addition, Jean Luc Marion, the French phenomenologist and theologian in his God without being (1995), claims that even Thomas Aquinas was influenced by the NeoPlatonists. Marion tries to transcend the notion of God that is married to Greek ontology (Hankey 1999:389, 403-405). If Christian theology agrees to take the Greek notion of Being (in its general expression), it cannot come to the untainted biblical concept of Trinity. Scriptures apparently reveal a different understanding of God. In this sense, the modern phenomenological movement has become critical towards the traditional Neo-Platonic formulation of God. Of course, Marion's critique is really an extension of Heidegger's critique of onto-theology and implicates the entire philosophical tradition, not just Neo-Platonism.

\section{Gnosticism and the Trinity}

Finally, the Christian understanding of the Trinity was also coloured by its dialogue with the most prevalent heresy of the 2nd century Gnosticism. Thomas Marsh, in his volume The Triune God: A Biblical, Historical and Theological Study, recognises this influence (Marsh 1994):

Though its orthodox critics were concerned with many other aspects of Gnostic teaching, the Gnostic portrayal of a nonincarnate Christ who was a divine emanation or aeon inferior in being to the Supreme God was a particular challenge to Christian faith which these writers felt obliged to meet and expose. (p. 69)

This debate between the gnostic Christ and the biblical Christ was crucial in developing some account of subordinationism.

Speaking about the complex influence of Greek philosophy on the Christian notion of the Trinity, Christoph Schwöbel (2009) correctly observes:

The ontological clarification was not only necessary to reject suspected heresies. It was also an inner necessity if one wanted to defend the claim of Christian faith to be the true philosophy. On the other hand, the ontological conceptuality provided by the various schools of philosophers could not without modification express the unity of God in different identities, which we have interpreted as a major characteristic of biblical discourse of God. (p. 39)

A summary is been provided of the influence of Greek philosophy on the church fathers in their development of the doctrine of Trinity. Though the metaphysical formulations of the fathers served a valuable apologetic purpose, the primitive Christian doctrine of the Trinity still might have drifted from the original apostolic expression of the doctrine. This necessitates a further clarification of the basic differences between the traditional church's trinitarian formula and the biblical doctrine of triune God. 


\section{The traditional trinitarian formula and the biblical Trinity}

There was immediate confusion in traditional formulae of the Trinity regarding the understanding of the terms persona and hypostasis. The Greeks (the Greek fathers) rejected the Latin persona, because it led to some forms of Sabellianism (the term signifies the mask used in the theatre). However, Latin theologians rejected the term hypostasis, because it implies substance and led to Arianism. (Arius claimed that there are three substances in God of which two are subordinate [subordinationism]). The so-called solution came from St. Basil who made a distinction between ousia and hypostasis. Ousia refers to what is common to all three Persons of the Godhead whilst hypostasis signifies what individuates them (Garrigou-Lagrange 1952:157).

However, theses definitions of ousia and hypostasis remained questionable. Catherine Mowry LaCugna (1986), from the University of Notre Dame, observes:

Theologians of East and West still attached significantly different meanings to key words such as hypostasis, prosopon, substantia, subsistentia, essentia, natura. And the one word which was supposed to settle the Christological controversies, homoousios (same substance), still had Sabellian overtones to the Greek ear, while homoiousios (similar substance) had Arian overtones to the Latin ear. (p. 176)

Moreover, Nathan Jacobs recognises this tension and objection against the Cappadocian formula. Responding to Leftow and Brümmer, who share the intuition that any trinitarianism that affirms genuine individuation of the hypostases was no different from polytheism with likeminded gods, he argues that 'this objection displays a gross misunderstanding of Patristic metaphysics, and demonstrates how, when playing by the Cappadocians' rules, there are significant differences between polytheism and monotheism' (Jacobs 2008:332).

Regarding the problem of defining persona, Karl Rahner in his criticism of the concept, asked: ' $[I] \mathrm{s}$ the concept person suitable to express faithfully that which is meant in connection with the doctrine of the Trinity' (Rahner, in Havrilak 1990:63). Acknowledging the problem is one of linguistic context. Rahner admitted that an understanding of 'person' with reference to the trinitarian God could not follow our interpretation of the term used elsewhere. By claiming that there are three 'persons' in God, 'we generalise and add up something that cannot be added up' and somehow lose track of the one uniting principle of God, the common essence. The Orthodox theologian Gregory Havrilak (1990) concludes:

So, the problem is complicated in the Trinitarian sense, in that we are compelled to think of 'persons' in the Godhead who are 'individuals' and 'distinct,' while simultaneously sharing a common life. Hence, the unavoidable dilemma: either we accept a Sabellian modalism where the persons are seen as mere emanations, or we adopt a form of tritheism as the alternative. (p. 63)

Rahner recognised that the Bible does not speak about personas. Thus, it might not represent the true difference between the Father, Son and Holy Spirit. ${ }^{6}$ Even Karl Barth argued that substantia is a better term than persona. Rahner was under the influence of Greek fathers and eastern conceptions of the Trinity that is first viewed as a mystery of salvation (Havrilak 1990:70). Rahner, though faithful to the Greek fathers, still confirmed the primacy of Scripture, even if he did it unconsciously. The biblical concept of the Trinity, with its emphasis on the unity and mystery of God, seems incompatible with the Hellenistic expressions of the doctrine.

Augustine once said:

When you ask 'Three what?' human speech labours under a great dearth of words. So we say three persons, not in order to say that precisely, but in order not to be reduced to silence. (De Trinitate, V. 9-10 quoted in Marsh 1994:133)

Upon analysis, the expression persona seems a desperate attempt to recognise the distinguished roles within the Trinity in the process of salvation rather than an expression of the metaphysical realities within divinity. Ontologically speaking, there is always the danger that even some contemporary 'social' theories of the Trinity may demonstrate 'a new version of polytheism' (Tuggy 2013:186). ${ }^{7}$

Nevertheless, the trinitarian nature of God is indispensable both as a doctrinal expression and in order to maintain an orthodox view of salvation. Wolfhart Pannenberg (2007), the celebrated theologian of revelation, in his article 'God of the philosophers', speaks about the necessity of affirming the trinitarian nature of divinity:

Theology that is distinctively Christian will attribute creation to the Trinitarian God-Father, Son, and Holy Spirit. In Christian theology, there is no room for a pre-Trinitarian monotheism of the one God. In our time of intense interreligious discussion, Christians cannot compromise the truth that the Trinitarian conception of God is not simply a Christian addition to a monotheism that we otherwise share with others. The Christian insistence is that God as such is to be understood as a differentiated unity. An undifferentiated unity means unity opposed to the many. Unity that is opposed to the many presupposes and therefore is conditioned by that opposition. Precisely because that is a conditioned unity, it cannot be the absolute unity that is before and above the many. Only the triune God, as differentiated unity, is absolutely and unconditionally the one God. It follows that true monotheism is trinitarian. (Pannenberg 2007:33)

This expression of Trinity transcends the Greek philosophical influences by refraining from offering definitions of Trinity. What is needed, Pannenberg argues, is dehellenisation of the Christian concept of trinity. Considerable obstacles, nevertheless, must be overcome (Pannenberg 2007):

Viewed in perspective, however, the program of dehellenizing Christian thought was not a lasting movement in modern Protestant theology. Aristotle may not have fared well, but the Platonic-Augustinian tradition remains strong. (p. 32)

6.This unicity of essence implies and includes the unicity of one single consciousness and one single person, although of course the unicity of one self-presence in and one single person, although of course the unicity of one self-presence in consciousness and freedom in the divine Trinity remains determined by that mysterious three-ness which we profess about God when we speak haltingly of the
Trinity of persons in God' (Rahner, in Havrilak 1990:65).

7.'A loving community of divine friends' has been a popular image of Trinity Nevertheless, the theory ends up in believing in a group of gods 'which is itself somewhat self-like' (Tuggy 2013:186). 
Adolf von Harnack (1851-1930), a prominent church historian and German theologian, once said:

Rejecting the Old Testament in the second century was a mistake that the main body of the church properly rejected; keeping it in the sixteenth century was a destiny from which the Reformation was not yet able to extricate itself; but to continue keeping the Old Testament within Protestantism as a canonical authority after the nineteenth century is a consequence of a paralysis of religion and the church. (Harnack, in Schwöbel 2009:23)

Dehellenisation of the doctrine of Trinity might be an ongoing project. The narrative aspect of Trinity as the God of love and its economic and salvific nature must receive more emphasis. ${ }^{8}$ This seems closer to the biblical worldview. Stanley J. Grenz, one of the most notable evangelical theologians, affirmed the importance of ontological or metaphysical differentiations within divine unity (Grenz 1994:67). Nevertheless, he also speaks about the economic nature of Trinity, namely that all three Persons are involved in every area of God's work and 'each is dependent on the work of others for the fulfilment of one divine program' (Grenz 1994:68). Apparently, the economic nature of Trinity points to the salvific nature and program of God and ultimately to a fuller understanding of deity, only through love as the relational essence of God (Grenz 1994:72). In this sense, Grenz joins the rank of theologians who transcend the traditional ontological view of Trinity and open some new vistas for the dehellenisation of the understanding of a triune God. An important aspect of this project is the acceptance of trinitarian dogma as mystery.

Stephen T. Davis in his Logic and Nature of God, claims that Trinity is not a doctrine, but a mystery (Davis 1983:135, 141). Though every doctrine contains an element of mystery, the traditional doctrine of Trinity might cease to be a Christian doctrine if it is formulated only in its cognitiverational understanding of the theological task. The Catholic theologian, Richard P. McBrien in his magnum opus Catholicism (1994), defends this position:

The Trinity is an absolute mystery in the sense that we do not understand it even after it has been revealed. It is a mystery in that it is 'hidden in God [and] cannot be known unless revealed by God.' It is an absolute mystery in that it remains such forever. (p. 316)

This principle has been confirmed by Millard Erickson, the notable evangelical theologian. 'The Trinity is incomprehensible. We cannot fully understand the mystery of Trinity,' claims Erickson (1996:338). Therefore, the dogma of the Trinity defies any rational and cognitive grasp of the ultimate nature of divine. Does this mean that there is no need for philosophy or theological reflection? LaCugna (1986) answers as follows:

8.'The history of love has both eternal and temporal dimensions. In the ordoessèndi, God's inner history as God (God's self-love in the self-relatedness of "Father, Son, Spirit") is taken to be the same as God's external history as God (God loving what is other than God, in creation, incarnation, sending of the Spirit). In the form of is other than God, in creation, incarnation, sending of the Spirit). In the form of Rahner's axiom, "The "economic' trinity is the "immanent" trinity and vice versa". In the ordocognoscendi, Christian religion arises out of the experience of this portion of God's history. As Christian theology reflects on that experience, it is no concerned with predicating attributes (wisdom, or even love) indifferently of "deity in general." Rather, Christian theology asks who this God is, who acts in this history, with these people. A narrative account is therefore unavoidable. And so, in the ordointerpretandathe trinitarian answer to the "who" of God is: God is love itself" (LaCugna 1986:173)
Theologians need philosophers in the task of self-critical assessment of the doctrine: Philosophers can challenge theologians to be more exact in our formulations, and more consistent in our systematization of history, exegesis, doctrine and theology. The cumulative effect of a joint dialogue might even be the restoration of a doctrine that for too long has only been collecting dust on the shelves of church history. (p. 179)

It must be added that the restoration must seriously consider 'biblical philosophy' and the exegetical task. What is needed is a biblical-philosophical re-formulation of the traditional formula of the Trinity. The task is worded as follows by Schwöbel (2009):

Viewed from this perspective, the formulation of Trinitarian doctrine is dependent on the language of God, expressing that differentiated unity in the Old as well as in the New Testament. Its technical expressions hypostasis, ousia, homousios, koinonia, idion, etc. appear as abbreviations of what could already be found in the Old and New Testaments in narrative and doxological forms. In order to say exactly what they mean, one has to go back to the biblical texts and their grammar, their way of relating different identities within the unity of agency and being of the one Lord. This would mean that the technical expressions of the doctrine of the Trinity constantly need to be filled with the content of the biblical witnesses because this is their subject-matter. (p. 37, [author's own emphasis])

Therefore, the 'doing theology in a Trinitarian fashion' always starts, not first and foremost with Athens, but with Jerusalem $^{9}$ though the final formulation of the doctrine should be done in the context of dialogue between Athens and Jerusalem. The Bible takes precedence over Greek philosophy, though methodologically speaking, the language of the communication may play a role in the conversation with contemporary philosophy in the rational expressions of faith.

John Behr, the Orthodox theologian, in his article 'The Trinity: Scripture and the Greek Fathers', concludes:

Such, then, is how the Greek Fathers, following Scripture, maintained that there is but one God, whose Son and Spirit are equally God, in a unity of essence and of existence, without compromising the uniqueness of the one true God. (Behr 1999:23, [author's own emphasis])

\section{Conclusion: Implications of trinitarian dogma for contemporary theology and African theology}

In summarising this research on the influence of Greek philosophy on the Christian doctrine of the Trinity, there might be an alternative to Behr's conclusion. The Greek a trinitarian fashion will always have to start from Jerusalem, from the biblical witnesses which provoked the formulation of the doctrine of the Trinity. The doctrine of the Trinity was not invented at Athens. The only doctrine of the Trinity that was ever invented at Athens, at least metaphorically, if not geographically, the triadic philosophy of Porphyry, was decidedly anti-Christian. However, starting from Jerusalem, from the biblical witnesses, trinitarian theology will have to travel to Athens because the truth claim involved in the trinitarian claim that God's history Athens because the truth claim involved in the trinitarian claim that God's history with Israel finds its eschatological form in Christ through the Spirit necessitates engagement with competing philosophical claims to universality. However, having arrived at Athens trinitarian theology will have to touch base with Jerusalem again in order to link the conceptsof philosophical reasoning to the contents of biblica witness. There is no middle road, no via media, between Athens and Jerusalem. Rather, trinitarian theology will have to act as a constant go-between between Jerusalem and Athens' (Schwöbel 2009:41). 
fathers, indeed following the biblical mystery of the unity of the triune God, still formulated their doctrine of the Trinity using the conceptual framework of Greek philosophy. Though the doctrine did not originate in Athens, and the Church fathers apparently justified their formulas with the perspicuous biblical teaching of the triune God, the Greek fathers still based their dogmatic method and content on a Greek philosophical theoretical framework. This calls for an alternative reformulation of the doctrine based on sound biblical investigation and fresh contemporary expression.

An attempt will be make to draw some implications of this research for the development of a contemporary and contextual theology of the Trinity.

Firstly, according to postmodern evaluation, 'faith has no need of thinking of Being' (Derrida 1987). Views of God derived from revelation should remain distinguished from the philosophical concepts of God. This does not mean that Christian philosophy or philosophy of religion is superfluous. It is a call for a reinvention of the philosophical language about the Trinity based primarily on biblical imagery and concepts. In the 'postmodern' (hopefully wholly biblical, but still relevant) expression of the triune God, without the philosophical notion of Being, the attention should focus more on the hermeneutical key of the redemption found in the Bible. This provides the bedrock imagery of the economic (salvific) revelation of the Trinity. In the Bible, the triune God has been revealed as the triune God of redemption rather than in primarily metaphysical and ontological aspects.

Secondly, the inherited theological trinitarian language or the language about God in general (under Greek influence) should be complemented by both Old and New Testament narrative and doxological language. Obtaining a clearer idea about the narratives and praises of God from Scripture might aid in coming to a broader and deeper understanding of the Trinity. After all, the revelation of God is not only propositional, but also based on the encounter with the divine person. The liturgical theology might help us better to comprehend the dynamical nature of God.

Thirdly, by transcending postmodern expressions of faith today which is highly critical of the rational articulated structures of faith, we can appreciate the post-postmodern emphasis on the adoration of mystery (cf. Santrac 2008). Within the biblical framework, this would provide the opportunity for a new orthodox expression of faith in the Trinity. At the same time, it may help us to experience God as mystery and learn to live with the triune God we do not fully understand.

Finally, there is at least one important implication of the dehellenised understanding of God as mystery for the relevant context of an African theology of the triune God. James Kombo, in his article 'The Trinity in Africa' (2009), recognises that the mysterious nature or essence of the preChristian experience of one God, the Father NTU, provides the substratum for the emergence of an alternative African Christian notion of the Trinity. He sees the need for the reexamination of traditional expressions of the doctrine. ${ }^{10}$ In its cultural context, the adoration of God becomes much more plausible than full comprehension of the dynamic nature of the trinity. John Behr, by quoting Melanchton, becomes aware of this important point (Behr 1999):

Defining the doctrine of the Trinity as a mystery which cannot be fathomed by unaided human reason invites a position such as Melanchthon's: 'We adore the mysteries of the Godhead. That is better than to investigate them'. (p. 22)

The Christian heritage confirms this theological and spiritual reality. Being less flamboyant, dogmatic, philosophical, theological and traditional, we should again go back to the Scriptures where we will certainly rediscover the doctrine and/or the mystery of the Holy Trinity based on the wellknown proposition of St. Anselm, who in his Augustinian spirit proclaims 'Three I know not what' (tresnescio quid) (St. Anselm, in Marsh 1994:133).

\section{Acknowledgements Competing interests}

The author declares that he has no financial or personal relationship(s) which may have inappropriately influenced him in writing this article.

\section{References}

Allen, D., 1985, Philosophy for understanding theology, John Knox Press, Atlanta.

Behr, J., 1999, 'The Trinity: Scripture and the Greek Fathers', Living Pulpit 8(2), 22-23.

Davis, S.T., 1983, Logic and nature of God, Eerdmans, Grand Rapids, MI.

Derrida, J., 1987, Psyche: Inventions de I'Autre, Galilee, Paris. PMid:9898766

Dillon, J., 1989, 'Logos and trinity: Patterns of Platonist influence on early Christianity', in G. Vesey (ed.), The philosophy in Christianity, pp. 1-14, Cambridge University Press, Cambridge. PMid:2913604

Erickson, M.J., 1996, Christian theology, Baker Book House, Grand Rapids, MI.

Garrigou-Lagrange, R., 1952, The trinity and God the creator: A commentary on St. Thomas' Theological Summa, B. Herder Book Co., London.

Gaston, T.E., 2009, 'The influence of Platonism on the early Apologists', The Heythrop Journal July, 573-580. http://dx.doi.org/10.1111/j.1468-2265.2008.00448.x

Grenz, S.J., 1994, Theology for the community of God, Broadman \& Holman Publishers, Nashville, TN.

Hankey, W.J., 1999,'Theoria versus poesis: Neoplatonism and Trinitarian difference in Aquinas, John Milbank, Jean-Luc Marion and John Zizioulas', Modern Theology 15(4), 387-415. http://dx.doi.org/10.1111/1468-0025.00105

Havrilak, G., 1990, 'Karl Rahner and the Greek trinity', St. Vladimir's Theological Quarterly 1, 61-77.

10.The African pre-Christian experience of God has turned out to be the gate through which Yahweh has penetrated Africa. This does not only mean that for the African Christians the Trinity must emerge from Nyambe, Nyame, Nyasaye, and so on as various African peoples call God - but also that the Son and the Holy Spirit are now constitutive in the identity of those names. In this case, confession of one God (monotheism) is not in the 'common substance-essence' terms of the Greco-Roman heritage, nor in the 'monotheism as one-ness, non-divisible essence' in Islam and Neo-Platonism, nor as oneness in the sense of 'absolute subject' in the philosophy of Idealism. Here, oneness of God is confessed in the context of the fatherhood as contemplated from the point of view of the Father whose NTU is split between the Son and the Holy Spirit. The Father in this case is the 'Gre is Muntu' (God) the Son and the Holy Spirit. The Father in this case is the 'Great Muntu' (God) who uniquely shares the Divine NTU with the Son and the Holy Spirit. In this mix of things, four things are noteworthy: (1) there emerges yet another way of thinking about God, (2) the Christian faith receives alternative resources for renewal of the church, (3) assumptions of conventional theological thinking are once again re-examined, and (4) Christians have an opportunity to use their own cultural identity for God's glory' (Kombo 2009, abstract). 
Jacobs, N., 2008, 'On "not three Gods"-again: Can a primary-secondary substance reading of ousia and hypostasis avoid tritheism?', Modern Theology July, 331-358. reading of ousia and hypostasis avoid tritheism?", Mod

Kombo, J., 2009, 'The trinity in Africa,' Journal of Reformed Theology 3(2), 125-143. http://dx.doi.org/10.1163/156973109X448698

Lacugna, C.M., 1986, 'Philosophers and theologians on the trinity', Modern Theology April, 169-181. http://dx.doi.org/10.1111/j.1468-0025.1986. tb00112.x

Marion, J.L., 1995, God without being, University of Chicago Press, Chicago.

Marsh, T., 1994, The triune God: A biblical, historical, and theological study, TwentyThird Publications, Mystic, CT.

McBrien, R.P., 1994, Catholicism, HarperCollins Publishers, New York.
Pannenberg, W., 2007, 'God of the philosophers', First Things June-July, 31-34.

Partenie, C., 2011, 'Plato's myths' in E.N. Zalta (ed.), The Stanford Encyclopedia of Philosophy, Stanford University Press, Redwood City, CA, viewed 02 October 2013 from http://plato.stanford.edu/entries/plato-myths/

Santrac, A.S., 2008, 'Beyond postmodernism: Are we aware of the new world view', viewed 23 April 2012, from http://www.aleksandarsantrac.info/docs/ Unpublished/Beyond\%20Postmodernism.pdf

Schwöbel, C., 2009, 'The trinity between Athens and Jerusalem', Journal of Reformed Theology 3(1), 22-41. http://dx.doi.org/10.1163/156973109X403705

Stead, C., 1989, 'Augustine's philosophy of being', in G. Vesey (ed.), The philosophy in Christianity, pp. 71-84, Cambridge University Press, Cambridge.

Tuggy, D., 2013, 'Hasker's quests for a viable social theory,' Faith and Philosophy 30(2), 171-187. http://dx.doi.org/10.5840/faithphil201330213 